\title{
ANALYSIS OF THE LINKAGE OF METALS MINING SECTOR WITH NATIONAL ECONOMIC
}

\author{
ANALISIS KETERKAITAN SEKTOR PERTAMBANGAN MINERAL \\ LOGAM TERHADAP PEREKONOMIAN NASIONAL
}

\author{
TRISWAN SUSENO, MEITHA SUCIYANTI and NENDARYONO MADIUTOMO \\ Research and Development Centre for Mineral and Coal Technology \\ Jalan Jenderal Sudirman 623 Bandung 40211 \\ Ph. (+6222) 6030483, Fax. (+6222) 6003373 \\ e-mail: triswan.suseno@esdm.go.id
}

\begin{abstract}
Metals mining is one of the sectors that drives the national economy, and produced to meet the needs of human life. Almost all industries need this sector as an input either directly or indirectly. Each creation of the output from this sector requires an input from many other industries. The role of this sector can be traced by calculating its spreading (downstream linkages) and its degree of sensitivity (upstream linkages) of any other sectors in the country. The data used for supporting this calculation comes from trade transactions among sectors that have been compiled into Indonesian input-output tables. The objective of this study is to find the impact of metals mining sector on the regional economy. The method is conducted through approach of input-output analysis. Based on the calculation using inputoutput table analysis, it appears that there are four sectors that almost all its domestic outputs are able to fulfill the needs of other sectors in the country, i.e. tin-, gold-, silver- and other metals processing sectors. In other words, these four sectors have a high downstream linkage to other sectors in the country. The upstream linkages of these four sectors are also quite large because almost all other sectors in the country utilize the products of these sectors, either directly or indirectly. While the output of copper processing sector is almost entirely for exports. It indicates that the other industries in the country have not been able to capitalize this sector products due to various constraints such as technologies and investment in the processing and purification. This means that the copper mining sector has a low downstream linkage to the other sectors in the country, while the upstream linkage of this sector is very small, as the sector does not much utilize the product from other available in the country for the production process. The four sectors are more impactful since they have a high level of upstream and downstream linkages to the other industry sectors in the country compared to the copper mining sector.
\end{abstract}

Keywords: linkage, coefficient, sector, input, output

\section{ABSTRAK}

Sektor pertambangan mineral logam merupakan salah satu sektor yang menjadi penggerak roda perekonomian nasional. Sektor ini diproduksi untuk memenuhi kebutuhan hidup manusia. Hampir semua industri membutuhkan sektor ini sebagai input, baik secara langsung maupun tidak langsung. Sebaliknya, setiap penciptaan output sektor ini banyak membutuhkan input dari berbagai industri lainnya. Peran sektor ini dapat ditelusuri dengan cara menghitung daya penyebaran (keterkaitan hilir) dan derajat kepekaan (keterkaitan hulu) terhadap setiap sektor lainnya di dalam negeri. Data yang digunakan untuk mendukung perhitungan ini adalah data transaksi perdagangan antarsektor yang telah disusun di dalam tabel input-output Indonesia. Tujuannya adalah untuk mengetahui dampak keberadaan sektor pertambangan logam terhadap perekonomian daerah. Metode yang digunakan untuk mengukur nilai keterkaitan ke hulu dan hilir adalah pendekatan analisis tabel input-output. Berdasarkan hasil perhitungan menggunakan analisisi tabel input-output, terlihat ada 4 sektor yang hampir seluruh output domestiknya mampu memenuhi kebutuhan sektor lain di dalam negeri, yaitu pengolahan timah, pengolahan barang tambang logam lainnya, pengolahan emas dan pengolahan perak. Dengan kata lain, keempat sektor tersebut memiliki keterkaitan hilir yang tinggi terhadap sektor lainnya di dalam negeri. Keterkaitan hulu keempat sektor ini juga cukup besar, karena hampir seluruh 
sektor lainnya di dalam negeri banyak memanfaatkan produk keempat sektor ini, baik secara langsung maupun tidak. Output dari sektor tembaga hampir seluruhnya diekspor. Hal ini menunjukkan bahwa sektor industri lain yang ada di dalam negeri belum mampu memanfaatkan produk sektor ini, karena berbagai kendala seperti teknologi dan investasi dalam pengolahan dan pemurniannya. Artinya bahwa sektor pertambangan tembaga memiliki keterkaitan hilir rendah terhadap sektor lainnya di dalam negeri. Keterkaitan hulu sektor ini sangat kecil, karena sektor ini tidak banyak memanfaatkan produk-produk dari sektor lainnya yang ada di dalam negeri untuk proses produksinya. Keempat sektor tersebut yaitu pengolahan timah, pengolahan emas, pengolahan perak, dan pengolahan barang tambang logam lainnya lebih bermanfaat keberadaannya karena memiliki tingkat keterkaitan hulu dan hilir yang tinggi terhadap sektor industri lainnya di dalam negeri dibandingkan dengan sektor pertambangan tembaga.

Kata kunci: keterkaitan, koefisien, sektor, input, output

\section{INTRODUCTION}

The Central Bureau of Statistics (BPS) shows that the economic growth indicated by gross domestic product (GDP) in 2015 was Rp. 3,049 trillion, increase 4.79\% compared to 2014 , i.e. Rp. 2,909 trillion (BPS, 2016). Metal mining sector is one of the sectors that becomes part of the formation, but the sector of national GDP is only accounted for $1.41 \%$, although the increase is $0.35 \%$ compared to 2014 , which is only accounted for $1.16 \%$ (33.68 trillion). In the period of $2000-2015$, this sector experienced slow reduction in economic growth rate namely only around $3.02 \%$, whereas the national economy escalated an average of $5.42 \%$ per year.

Mineral resources are limited and unrenewable (Nahib, 2006). This sector is one of the driving forces in national economic growth, which is utilized by wide range of other economic sectors in the country, either as a raw material or as a final product, or in the form of intermediate goods and finished goods. In line with the opinion of Dault, Mudzakir and Suherman (2008), the development of metal mining sector also needs to be directed to increase its role in creating strong linkages with other sectors both backward (upstream) and forward (downstream) lingkages. For example, the metal mining sector output should be used optimally by the sector itself, metal processing, construction, and other sectors in the country. Otherwise, in order to produce an output, this sector should utilize the outputs from other sectors as production inputs. Thus, such conditions will create a close relationship among sectors, forms stable economic condition and competitiveness both at domestic and abroad.
The small contribution from this sector to the national GDP does not necessarily indicate low contribution to other economic sectors. Therefore, it is necessary to study how the linkages both forward and backward in this sector. A method for analyzing the inputoutput tables to measure the level of linkages is used as analytical tools, either directly or indirectly, and upstream or downstream. The data used in this study came from Input-Output Indonesia 2010, published by the Central Bureau of Statistics in 2015 (BPS, 2010) with the classification of 185 sectors. For the purpose of analysis, the author made modifications to the inputoutput table data into 54 sectors by bringing up the metal mining sector as the sector to be analyzed. The examined isseu is how the linkages in the metal mining sector, both forward and backward, affect the national economy. Analytical tool used for this study is the analysis of input-output tables, known as the Leontief linear input-output model in (Gaspersz, 1992; Karkacier and Bölük, 2017).

There are two types of linkage in the inputoutput model, i.e. backward and forward linkages. According to Kula (2008) and Vega (2013), backward linkage is a relationship of influences caused by one unit of final demand in the sector to the total purchase of inputs from all sectors in the economy, while forward linkage shows the corresponding of influences caused by one unit of final demand of a sector to the total sales output of all sectors of an economy (Mirza, Marwa and Mukhlis, 2015). The relationship among the industries in the economy of a country supports to increase the role of one sector to the other sectors (Chiu and Lin, 2012), which examines the relationship between the industrial sector and the transport industry in Taiwan. While Bekhet and 
Abdullah (2010) conducted a study of the relationship between the use of energy to support economic growth in the agriculture sector. The description of the linkages between sectors of production in an economy presented in the preparation of Input-Output tables were analyzed using a Leontief model (Reis and Rua, 2006). Meanwhile, according to Purnomo and Istiqomah (2008), the influence of backward linkages means that the level of stimulus created by the development of an industry on the development of other industries. While the influence of the forward linkage is the level of stimulation generated by the first industry for their input.

This model will be applied to analyze the role or contribution of metal mining sector through linkages upstream (backward linkages) and downstream (forward linkages) metal mining sector to other economic sectors in Indonesia. The goal is to determine the extent of linkages of this sector as measured by the power distribution and the degree of sensitivity to other sectors of the national economy.

Law number 4 of 2009 concerning Mineral and Coal Mining requires mining companies to process and refine their mining products prior to exporting abroad. In addition to protecting Indonesia's natural resources, the implementation of this law also aims to improve upstream, downstream and added value linkages. So far, Indonesia exports raw materials to developed countries, after being processed abroad into raw materials, semi-finished or finished materials, then the material is imported back to Indonesia with high prices. Therefore, utilization should prioritize the fulfillment of domestic needs.
Processing and purification of ore in the country will spur the development of industry, as a means of creating opportunities and employment opportunities, employment absorption, non-tax state revenues and exports that will be a great contributor to the national economy.

\section{METHOD}

The input-output models provide an information on transactions of goods and services as well as interconnections between units of economic activity for a certain period of time, which are presented in tabular form. Fields along the lines show the allocation of output, whilst fields along the column shows the use of inputs in the production process (BPS, 2016). Analysis of the model input-output table (I-O Table), called as linear model of Leontief inputoutput (Ke et al., 2016), is a tool that will be used to look at the linkages among economic sectors. According to Gaspersz (1992), Leontief I-O Table of an industry carries out production activities that receive input from several sources of raw materials, as well as from the industry itself. Then, the production from the industry will be allocated to some demand. I-O Table is a statistical description in a matrix form that shows transactions of goods or services between economic activities, as shown in Table 1 (Bulmer-Thomas, 1982; Nazara, 1997).

Output allocation can be formulated as shown in equation (1) below.

$\sum_{j=1}^{n} X_{i j}+F_{i}=X_{i} ; i=1,2, \ldots, n$

Table 1. Matrix of Transactions between economic sectors

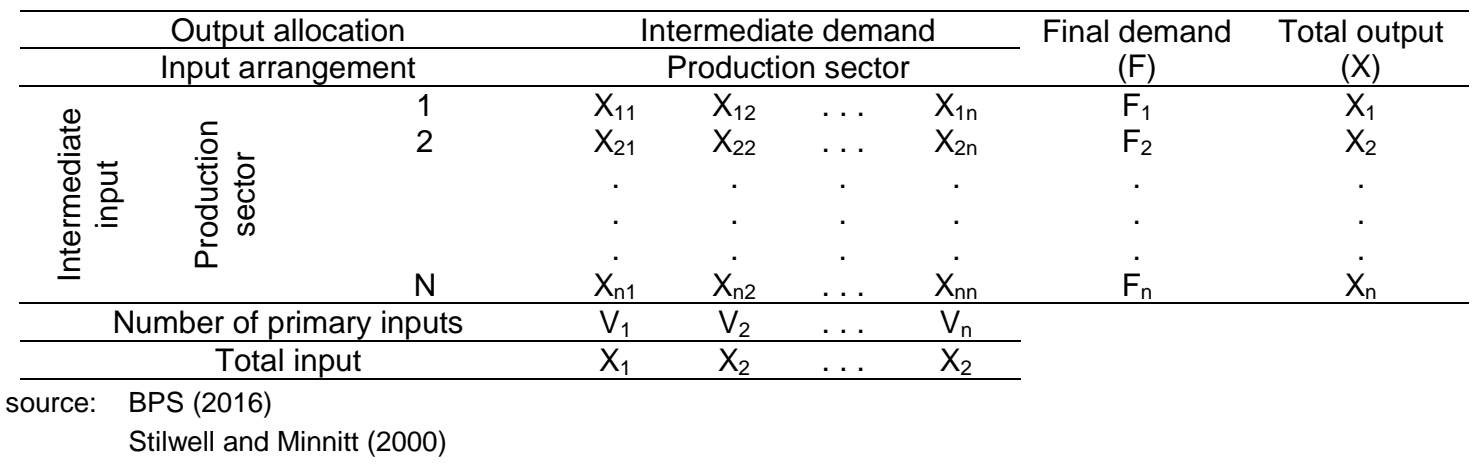


In this case, $X_{i j}$ is the number of output of sector $i$ used as input by sector $j, X_{i}$ is the output of sector $i, F_{i}$ is a final demand of sector i. While the composition of input is expressed in equation (2) below:

$\sum_{i=1}^{n} X_{i j}+V_{j}=X_{j} ; j=1,2, \ldots, n$

In this case, $X_{i j}$ is the number of input of sector $\mathrm{j}$ used as output by sector $\mathrm{i}, \mathrm{V}_{\mathrm{i}}$ is the input of value added of sector $j$; value added is another input that comes from nonindustrial that will be used in the production process (Pangaribuan, 2014).

Intermediate input coefficient or direct coefficient is the amount of input of sector $i$ used in sector $\mathrm{j}$ and divided by total input in sector $\mathrm{j}$, expressed in equation (3):

$a_{i j}=\frac{x_{i j}}{x_{j}}$

Input coefficient of value added ( $v$ ) of sector $\mathrm{i}$ used by sector $\mathrm{j}$ divided by the number of input of sector j, shown in equation (4):

$v_{k j}=\frac{v_{k j}}{x_{j}} \quad ; k=1,2, \ldots, m$

In this case, $V_{k j}$ is the value-added of $k$ component of the sector $j$ - output, $v_{k j}$ is coefficient value-added of $k$ component to the amount of sector $\mathrm{j}$ - output.

One of the most important components of Leontief input-output model is invers matrix Leontief. This matrix is the basic framework for a variety of economic analysis both in micro and macrolevel. This matrix serves a liaison between final demand and production levels that will be used to calculate the effect of final demand of the sector (in this case mining and metals) to the output level of other economic sectors in Indonesia, or vice versa. The model is shown in equation (5) as follows:

$X=(I-A)^{-1} F$.

In this case,

$\mathbf{X}$ is the output matrix,

$I$ is the identity matrix,

A is the coefficient matrix of total input,

$F$ is the final demand matrix, consisting of consumption, investment and exports.
Meanwhile, to determine the effect of final demand to the added value, it can be calculated using the following equation (6):

$X=\left(I-A^{d}\right)^{-1} F$

$\left(I-A^{d}\right)^{-1}$ is the coefficient matrix of domestic input.

One of the tables that can be derived from the analysis of I-O Table is backward linkage effect ( $\alpha$ j) and forward linkage effect $(\beta i)$. Index of backward linkage effect and forward linkage effect had been used by Zaini (2004) as follows:

Index of backward linkage effect illustrates the relative effect of the increase of one sector output to the increase of another sector output, which is expressed in equation (7):

$\propto_{j}=\frac{\sum_{i}^{n} b_{i j}}{\frac{1}{n} \sum_{i}^{n} \sum_{j}^{n} b_{i j}}$

Backward linkage effect is inverse matrix element number of sector $\mathrm{j}\left(\Sigma \mathrm{l} \mathrm{b}_{\mathrm{ij}}\right)$ that shows the effect caused by one unit of a sector final demand for all sectors (Ayas, 2017). Index of backward linkage effect is the ratio of backward linkage effect to the average matrix inverse of each column $\left(\frac{1}{n} \sum_{i}^{n} \sum_{j}^{n} b_{i j}\right)$.

In this case,

$\alpha_{j}$ is an index of backward linkage effect

$b_{i j}$ is the Leontief inverse matrix inverse element $(\mathrm{I}-\mathrm{A})^{-1}$ of the input coefficient sector $\mathrm{j}$ and sector I (Marconi, Rocha and Magacho, 2016)

$\mathrm{n}$ = number of economic sectors

Index of forward linkage effect illustrates relative effect of the increase in output of a sector to boost the increase of other sectors output (backward linkages).

$\beta_{j}=\frac{\sum_{j}^{n} b_{i j}}{\frac{1}{n} \sum_{i}^{n} \sum_{j}^{n} b_{i j}}$

Forward linkage effect is a number of matrix inverse by row $\mathrm{i}\left(\sum_{\mathrm{j}}^{\mathrm{n}} \mathrm{b}_{\mathrm{ij}}\right)$ gives a description of the effect caused by a unit of the final demand of all sectors of one sector (Mirza, Marwa and Mukhlis, 2015). Index of forward linkage effect is a ratio of forward linkage 
effect to the average of matrix inverse $\left(\frac{1}{n} \sum_{i}^{n} \sum_{j}^{n} b_{i j}\right)$.

In this case,

$\beta_{\mathrm{jk}}$ is an index of forward linkage effect

$b_{i j}$ is the Leontief inverse matrix inverse element $(\mathrm{I}-\mathrm{A})^{-1}$ of the input coefficients sector $\mathrm{i}$ and sector $\mathrm{j}$

$\mathrm{n}$ = number of economic sectors

Chifamba and Odhiambo (2015) mentioned the same item about both equations above as a backward linkages effect and relevance to the forward linkage effect (Muryani and Swastika, 2018). The result from the calculation of the backward linkages effect and forward linkage effect then compared to the certain value, which is 1 , so it has some criteria as follows (Mellyawanty et al., 2012):

Criteria for backward linkages effect:

If $\alpha j=1$, meaning that backward linkages effect of sector $j$ equal to the average of backward linkages effect across economic sectors.

If $\alpha_{j}>1$, meaning that backward linkages effect of sector $\mathrm{j}$ is higher than the average of backward linkages effect across economic sectors.

If $\alpha_{j}<1$, meaning that backward linkages effect of sector $j$ is lower than the average of backward linkages effect across economic sectors.

Criteria for forward linkage effect:

If $\beta_{i}=1$, meaning that forward linkages effect of sector $\mathrm{j}$ equal to the average of forward linkages effect across economic sectors.

If $\beta_{i}>1$, meaning that forward linkages effect of sector $j$ is higher than the average of forward linkages effect across economic sectors.

If $\beta_{i}<1$ meaning that forward linkages effect of sector $j$ is lower than the average of forward linkages effect across economic sectors (Zhang and Felmingham, 2002).

\section{Data}

The data used for analysis are input-output data 2010 compiled by BPS (2016) based on a matrix of transactions by classification of 185 sectors or production. For the purposes of analysis, the author simplify the number of qualifiers to 54 industry sectors. The sector that has not changed is the metallic mineral mining and processing sector with regard to the processing of metallic minerals, as well as the electricity sector. The agriculture, forestry and fishing (sector code 1-36), the processing sector (sector code 53-144 and 120), and the arrangement of the classification of 54 sectors in detail can be seen in Table 2 .

Table 2. Classification of input-output of 54 sectors

\begin{tabular}{|c|c|c|}
\hline code 54 & Description & code 185 \\
\hline 001 & Agriculture, Forestry, and Fisheries & $1-36$ \\
\hline 002 & Coal & 37 \\
\hline 003 & Crude oil & 38 \\
\hline 004 & Gas and Geothermal & 39 \\
\hline 005 & Sand Iron and Iron Ore & 40 \\
\hline 006 & Lead & 41 \\
\hline 007 & Bauxite & 42 \\
\hline 008 & Copper & 43 \\
\hline 009 & Nickel & 44 \\
\hline 010 & Other Metals Mining Goods Group & 45 \\
\hline 011 & Gold & 46 \\
\hline 012 & Silver & 47 \\
\hline 013 & Excavation Goods Any Type & 48 \\
\hline 014 & Metallic Minerals Mining Goods & 49 \\
\hline 015 & Coarse Salt & 50 \\
\hline 016 & Oil Mining Services & 51 \\
\hline 017 & Mining and Quarrying Other Services & 52 \\
\hline 018 & Processing Industry & $53-144$ and 120 \\
\hline 019 & Basic Iron and Steel Industry & 114 \\
\hline 020 & Base Metal Industry Not Iron & 115 \\
\hline
\end{tabular}


INDONESIAN MINING JOURNAL Vol. 22, No. 2, October 2019 : 129 - 143

\begin{tabular}{|c|c|c|}
\hline code 54 & Description & code 185 \\
\hline 021 & Goods Foundry Results & 116 \\
\hline 022 & Metal Building Materials & 117 \\
\hline 023 & $\begin{array}{l}\text { Weapons and Ammunition, Metallurgy and Metal Goods } \\
\text { Manufacturing Services }\end{array}$ & 118 \\
\hline 024 & Kitchen Tools, Carpentry, Appliances, and Office Of Metal & 119 \\
\hline 025 & Consumer Electronics, Communications and Fittings & 121 \\
\hline 026 & Measurement, Photography and Jewelry & 122 \\
\hline 027 & Plant Engineering and Electric Motors & 123 \\
\hline 028 & Electrical Engineering and Fittings & 124 \\
\hline 029 & Batteries & 125 \\
\hline 030 & Other Electrical Equipment & 126 \\
\hline 031 & Household Electrical Appliance & 127 \\
\hline 032 & Prime Mover & 128 \\
\hline 033 & Engineering Office and Accounting Purposes, Parts and Fittings & 129 \\
\hline 034 & Other Machinery and Fittings & 130 \\
\hline 035 & Except of Motor Vehicles Motorcycles & 131 \\
\hline 036 & Boats and Services Improvement & 132 \\
\hline 037 & Train and Improvement & 133 \\
\hline 038 & Flying planes and Service Improvement & 134 \\
\hline 039 & Other Transportation Equipment & 135 \\
\hline 040 & Electricity Procurement & 145 \\
\hline 041 & Gas Procurement & 146 \\
\hline 042 & Water Supply, Waste Management, Waste and Recycling & $147-148$ \\
\hline 043 & Construction & $149-153$ \\
\hline 044 & Wholesale and Retail Trade, Repair Cars and Motorcycles & $154-156$ \\
\hline 045 & Transportation and Warehousing & $157-163$ \\
\hline 046 & Provision of Accommodation and Eat Drink & $164-165$ \\
\hline 047 & Information and Communication & $166-169$ \\
\hline 048 & Financial Services and Insurance & $170-173$ \\
\hline 049 & Real Estate & 174 \\
\hline 050 & Company Services & $175-176$ \\
\hline 051 & Administration, Defense and Compulsory Social Security & 177 \\
\hline 052 & Education services & 178,181 \\
\hline 053 & Health Services and Social Activities & 179,182 \\
\hline 054 & Other Services & $180,183-185$ \\
\hline 1900 & Total Intermediate Input & \\
\hline 1950 & Taxes Minus Subsidies on Products & \\
\hline 2000 & Total Imports & \\
\hline 2010 & Workmen's Compensation & \\
\hline 2020 & Gross Business Surplus & \\
\hline 2030 & Other Subsidies Minus Taxes & \\
\hline 2090 & Gross Value Added & \\
\hline 2100 & Total Input & \\
\hline 1800 & Total Intermediate Demand & \\
\hline 3012 & Household consumption & \\
\hline 3020 & Consumption Non-profit institutions that serve households & \\
\hline 2030 & Government Konumsi & \\
\hline 3040 & Gross Fixed Capital Formation & \\
\hline 3070 & Inventory changes & \\
\hline 3090 & Total Demand End & \\
\hline 3100 & Total Demand & \\
\hline 4090 & Imports of Goods and Services & \\
\hline 5090 & Margin Trading and Transportation & \\
\hline 6090 & Taxes on Products Neto & \\
\hline 7000 & Total Output & \\
\hline 8000 & Total Demand & \\
\hline
\end{tabular}

Source: BPS (2016), reprocessed 


\section{RESULTS AND DISCUSSION}

\section{Upstream Linkages (Input Coefficients)}

In his article, Muryani and Swastika (2018) said that input-output models is used to analyze the relationship between backwards and forwards in the transport sector of the Indonesian economy and the multiplier effect on the Indonesian economy as a whole.

Table 3 illustrates the intermediate input coefficient matrix used by each sector in production. Its values are obtained using equation (3). For example, to calculate the coefficient of sector input (mining and quarrying other services) obtained by dividing the value of the sector (mining and quarrying other services), i.e. the amount Rp. 86,138 with the large number of inputs sector (sand iron and iron ore), namely Rp. 4,880.90, so the result is 0.0381 . Other input coefficient can be obtained by using the same method, and the results are shown in Table 3. Column 2 (Table 3) shows that in order to produce sector output (sand iron and iron ore), this sector requires input (domestic) of its own sector amounted to $0.05 \%$ from sector (Mining and Quarrying Other Services) of $38.14 \%$, sector (Processing Industry) of $4.47 \%$, sector (Plant Engineering and Electric Motors) of $0.09 \%$, sector (Other Electrical Equipment) of $0.06 \%$, sector (Other Machinery and Fittings) of $0.48 \%$, sector (Real Estate) of $0.03 \%$ and sector (Other Services) of $0.01 \%$. In other words, to produce sector output (Sand Iron and Iron Ore) of Rp. 1, this sector requires input of its own sector of Rp. 0.0005 , from sector (Mining and Quarrying Other Services) of Rp. 0.3814, sector (Processing Industry) of Rp. 0.0447, sector (Plant Engineering and Electric Motors) of Rp. 0.0009, sector (Other Electrical Equipment) Rp. 0.0006, sector (Other Machinery and Fittings) of Rp. 0.0048, sector (Real Estate) of Rp. 0.0003 and sector (Other Services) of Rp. 0.0001. Therefore, the number of intermediate inputs required by sector (Sand Iron and Iron Ore) to generate an output of Rp. 1 is Rp. 0.3323 , or approximately $33.23 \%$ from the total input and gross operating surplus amounted to 0.3957. The smallest total coefficient of intermediate input (domestic) is from sector (bauxite), which is only 0.0477 , but this sector is able to generate the highest gross operating surplus (2020) compared to other mineral mining sector, which is 0.8044 . While sector (silver) and (sand iron and iron ore) become the sector with the highest absorbing income (2010) that is equal to $27.19 \%$ and $20.84 \%$ respectively of the total output.

Input coefficient of added value contained in Table 3, obtained from the calculation using equation (4). Table 3 shows that the coefficient of added value of sand/iron ore sectors is 0.6094 , meaning that any output generated by this sector amounted to Rp. 1 would generate an added value of $\mathrm{Rp}$. 0.6094. This component consists of Rp. 0.2084 (wages and salaries or labour compensation), gross operating surplus of Rp. 0.3957 and taxes minus subsidies of other products amounting of Rp. 0.0054. The same explanation to other sectors in the metal mining groups.

Table 3. Inputs coefficient of each component in mineral mining sector *)

\begin{tabular}{ccccccccc}
\hline $\begin{array}{c}\text { Sector } \\
\text { code } \\
(1)\end{array}$ & $\begin{array}{c}\text { Sand Iron } \\
\text { and Iron Ore } \\
(2)\end{array}$ & $\begin{array}{c}\text { Lead } \\
(3)\end{array}$ & $\begin{array}{c}\text { Bauxite } \\
(4)\end{array}$ & $\begin{array}{c}\text { Copper } \\
(5)\end{array}$ & $\begin{array}{c}\text { Nickel } \\
(6)\end{array}$ & $\begin{array}{c}\text { Other Metals Mining } \\
\text { Goods Group } \\
(7)\end{array}$ & $\begin{array}{c}\text { Gold } \\
(8)\end{array}$ & $\begin{array}{c}\text { Silver } \\
(9)\end{array}$ \\
\hline 001 & - & - & - & - & - & - & 0.0002 & 0.0001 \\
005 & 0.0005 & - & - & - & - & - & - & - \\
006 & - & 0.0003 & 0.0001 & 0.0006 & 0.0007 & 0.0002 & 0.0001 & - \\
008 & - & 0.0006 & 0.0002 & 0.0012 & 0.0013 & 0.0004 & 0.0001 & - \\
009 & - & 0.0003 & 0.0001 & 0.0006 & 0.0007 & 0.0002 & 0.0001 & - \\
011 & - & 0.0003 & 0.0001 & 0.0006 & 0.0007 & 0.0002 & 0.0390 & 0.0179 \\
012 & - & - & - & - & - & - & 0.0018 & 0.0008 \\
013 & - & 0.0002 & 0.0001 & 0.0004 & 0.0005 & 0.0001 & 0.0000 & - \\
017 & 0.0381 & 0.0301 & 0.0109 & 0.0587 & 0.0648 & 0.0186 & 0.0229 & 0.0107 \\
018 & 0.0447 & 0.0289 & 0.0109 & 0.0428 & 0.0689 & 0.0235 & 0.0512 & 0.0224 \\
025 & - & 0.0001 & - & 0.0001 & 0.0001 & - & 0.0005 & 0.0002 \\
027 & 0.0009 & - & - & - & - & - & 0.0001 & 0.0000 \\
028 & - & - & - & 0.0001 & 0.0001 & - & 0.0004 & 0.0002 \\
\hline
\end{tabular}


INDONESIAN MINING JOURNAL Vol. 22, No. 2, October 2019 : 129 - 143

\begin{tabular}{ccccccccc}
\hline $\begin{array}{c}\text { Sector } \\
\text { code } \\
(1)\end{array}$ & $\begin{array}{c}\text { Sand Iron } \\
\text { and Iron Ore } \\
(2)\end{array}$ & $\begin{array}{c}\text { Lead } \\
(3)\end{array}$ & $\begin{array}{c}\text { Bauxite } \\
(4)\end{array}$ & $\begin{array}{c}\text { Copper } \\
(5)\end{array}$ & $\begin{array}{c}\text { Nickel } \\
(6)\end{array}$ & $\begin{array}{c}\text { Other Metals Mining } \\
\text { Goods Group } \\
(7)\end{array}$ & $\begin{array}{c}\text { Gold } \\
(8)\end{array}$ & $\begin{array}{c}\text { Silver } \\
(9)\end{array}$ \\
\hline 030 & 0.0006 & 0.0001 & - & 0.0002 & 0.0003 & 0.0001 & 0.0003 & 0.0001 \\
031 & - & 0.0003 & 0.0001 & 0.0007 & 0.0007 & 0.0002 & 0.0006 & 0.0003 \\
033 & - & 0.0030 & 0.0010 & 0.0060 & .0064 & 0.0018 & 0.0013 & 0.0006 \\
034 & 0.0048 & 0.0055 & 0.0021 & 0.0114 & 0.0130 & 0.0037 & 0.0155 & 0.0071 \\
035 & 0.0089 & 0.0011 & 0.0004 & 0.0021 & 0.0023 & 0.0007 & 0.0058 & 0.0027 \\
040 & 0.0002 & 0.0006 & 0.0002 & 0.0011 & 0.0012 & 0.0003 & 0.0006 & 0.0003 \\
042 & - & 0.0002 & 0.0001 & 0.0004 & 0.0005 & 0.0001 & - & - \\
043 & 0.1604 & 0.0205 & 0.0074 & 0.0398 & 0.0440 & 0.0126 & 0.0111 & 0.0053 \\
044 & 0.0205 & 0.0056 & 0.0023 & 0.0098 & 0.0116 & 0.0034 & 0.0283 & 0.0129 \\
045 & 0.0294 & 0.0196 & 0.0073 & 0.0359 & 0.0414 & 0.0118 & 0.0252 & 0.0117 \\
046 & 0.0001 & 0.0002 & - & 0.0005 & 0.0002 & 0.0002 & 0.0001 & - \\
047 & 0.0114 & 0.0016 & 0.0006 & 0.0031 & 0.0034 & 0.0010 & 0.0076 & 0.0035 \\
048 & 0.0112 & 0.0025 & 0.0009 & 0.0054 & 0.0059 & 0.0018 & 0.0079 & 0.0032 \\
049 & 0.0003 & 0.0002 & 0.0001 & 0.0003 & 0.0004 & 0.0001 & 0.0002 & 0.0001 \\
050 & - & 0.0082 & 0.0026 & 0.0113 & 0.0178 & 0.0044 & 0.0271 & 0.0125 \\
051 & - & - & - & - & - & - & 0.0016 & 0.0007 \\
052 & - & 0.0001 & - & 0.0002 & 0.0003 & 0.0001 & - & - \\
053 & - & 0.0001 & - & 0.0002 & 0.0003 & 0.0001 & 0.0002 & 0.0001 \\
054 & 0.0001 & - & - & 0.0001 & 0.0001 & - & - & - \\
1900 & 0.3323 & 0.1305 & 0.0477 & 0.2336 & 0.2876 & 0.0856 & 0.2500 & 0.1136 \\
1950 & 0.0107 & 0.0052 & 0.0017 & 0.0108 & 0.0116 & 0.0034 & 0.0088 & 0.0040 \\
2000 & 0.0477 & 0.0401 & 0.0139 & 0.0978 & 0.0789 & 0.0193 & 0.0661 & 0.0328 \\
2010 & 0.2084 & 0.1042 & 0.1245 & 0.0790 & 0.0792 & 0.1099 & 0.2055 & 0.2719 \\
2020 & 0.3957 & 0.7131 & 0.8044 & 0.5733 & 0.5375 & 0.7744 & 0.4637 & 0.5703 \\
2030 & 0.0053 & 0.0069 & 0.0078 & 0.0055 & 0.0052 & 0.0075 & 0.0059 & 0.0074 \\
2090 & 0.6094 & 0.8242 & 0.9367 & 0.6578 & 0.6220 & 0.8917 & 0.6751 & 0.8496 \\
2100 & 1.0000 & 1.0000 & 1.0000 & 1.0000 & 1.0000 & 1.0000 & 1.0000 & 1.0000 \\
\hline
\end{tabular}

Note: ${ }^{*}$ ) Based on the I-O Table of transaction Indonesia in 2010.

The upstream linkage described in the input coefficient between (1900) that the upstream bauxite sector linkage has the smallest value of 0.0477 , but creates the greatest added value (0.9367) among other sectors in other metals mining group. This means to produce an output of $\mathrm{Rp} .1 .00$, only requires raw materials from various sectors in the country by 0.0477 . Although the required amount is 0.0477 but the required inputs are obtained from 20 sectors of the economy (see Table 3). The copper, nickel and gold sectors represent the most absorbing sectors of input from other sectors, which are about 27 sectors to produce output. The copper, nickel and gold sectors are the three sectors that have the highest upstream linkages because they can absorb inputs from 27 sectors in the country. The bauxite sector is the smallest sector that uses inputs (products) from other sectors in the country that is only 0.0477 , the rest is imported.

\section{Downstream Linkages (Output Coefficient)}

The output coefficient is calculated by dividing products of sector $\mathrm{i}$, which is distributed to any other sectors, to total domestic output or $a_{1 j}=X_{1 j} / \Sigma X_{1 j}$. The results are presented in Table 4. For example, the amount of product sector (sand iron and iron ore) used by sector (processing industry) of Rp. $1,059,806$ divided by the output of sector (sand iron and iron ore) in the amount of Rp. $4,880,902$, so that the output coefficient $a_{i j}$ is 0.2171 . Output generated by sector (sand iron and iron ore) of Rp. 1 (see Column 2) distributed to meet the needs of its own sector of Rp. 0.0005 , for the needs of sector (processing industry) of Rp. 0.2171, sector (basic iron and steel industry) of Rp. 0.0102, sector (base metal industry not iron) of Rp. 0.2445 , sector (good foundry tesults) of Rp. 0.0044 , sector (metal building materials) of Rp. 0.1673, sector (weapons and ammunition, metallurgy and metal goods manufacturing services) of Rp. 0.0001 and sector (consumer electronics, communications and fittings) of Rp. 0.0001 .

Table 4 shows four sectors that almost all the domestic output capable to meet the needs of other sectors in the country: tin, other metals, gold and silver. While the sector that almost all its output is for export 
is copper, indicates that the other industries in the country have not been able to capitalize this sector due to various constraints, such as technology or economic investment for its processing and purification.

Each tin sector output is Rp. 1 and can be utilized by other sectors in the country only 0.2124 among others by sector 019, 020 and 021 . Copper sector utilized by the sector in the country of 0.0186 , i.e. by sector 006, 008, 009, 011, 018, 019, 020 and 021. Nickel output sector 0.4101 is utilized by 11 other sectors in the country those are by sector 002, 003, 007, 008, 009, 010, 011, 018, 019, 020 and 021. Sector that almost all its output utilized by sectors in the country are tin, gold and silver sectors (Table 4). While bauxite, copper and nickel sectors are 3 sectors that the output is the least utilized by other sectors in the country. Those are $0.2124,0.0186$ and 0.4101 . In other words, most of its output is sold or exported abroad. This shows that there is no industry in the country that is able to utilize the products from these 3 sectors due to technology limitations.

\section{Backward Linkage and Forward Linkage}

The height of backward linkage shows a high spread of impact changes in the sector to the other subsectors, in the upstream industries (input sector). The output of this sector will be the input for another, in the downstream sector. According to Harahap and Koestoer (2014), backward linkage index is a linkage value of a sector to the input value of other sectors. For example, if there is an increase in the value of the input in the sector $j$, it must be balanced with the increased value of the output of other sectors (sector i), because the input of sector $j$ obtained from the output of the sector $i$. This index is calculated using Equation (7), the coefficient obtained from the Leontief inverse matrix in Equation (6).

Table 4. Coefficient output of metal mining sector to other economic sectors

\begin{tabular}{|c|c|c|c|c|c|c|c|c|}
\hline \multirow[b]{2}{*}{$\begin{array}{l}\text { Sector } \\
\text { Code }\end{array}$} & \multicolumn{8}{|c|}{ Output of each sector } \\
\hline & $\begin{array}{l}\text { Iron Sand } \\
\text { and Iron } \\
\text { Ore }\end{array}$ & Tin & Bauxite & Copper & Nickel & $\begin{array}{l}\text { Other Metals } \\
\text { Mining } \\
\text { Goods } \\
\text { Group }\end{array}$ & Gold & Silver \\
\hline (1) & $(2)$ & (3) & (4) & (5) & (6) & $(7)$ & $(8)$ & (9) \\
\hline 002 & - & 0.0001 & - & - & 0.0001 & - & - & - \\
\hline 005 & 0.0005 & - & - & - & - & - & - & - \\
\hline 006 & - & 0.0003 & - & 0.0002 & 0.0006 & - & 0.0002 & - \\
\hline 007 & - & - & - & - & 0.0001 & - & - & - \\
\hline 008 & - & 0.0022 & - & 0.0012 & 0.0044 & - & 0.0011 & - \\
\hline 009 & - & 0.0003 & - & 0.0002 & 0.0007 & - & 0.0002 & - \\
\hline 010 & - & 0.0001 & - & - & 0.0001 & - & - & - \\
\hline 011 & - & 0.0001 & - & 0.0001 & 0.0002 & - & 0.0390 & 0.0097 \\
\hline 012 & - & - & - & - & - & - & 0.0034 & 0.0008 \\
\hline 017 & - & - & - & - & - & - & - & - \\
\hline 018 & 0.2171 & 0.1146 & - & 0.00212 & 0.0008 & 0.4222 & - & 0.0916 \\
\hline 019 & 0.0102 & 0.3663 & 0.0974 & 0.0070 & 0.1839 & 0.0880 & 0.3840 & 0.2280 \\
\hline 020 & 0.2445 & 0.3519 & 0.1137 & 0.0078 & 0.2167 & 0.1034 & 0.5111 & 0.5809 \\
\hline 021 & 0.0044 & 0.0042 & 0.0013 & 0.0001 & 0.0025 & 0.0012 & 0.0055 & 0.0051 \\
\hline 022 & 0.1673 & .1216 & - & - & - & 0.3600 & 0.0550 & 0.0834 \\
\hline 023 & 0.0001 & - & - & - & - & - & - & - \\
\hline 025 & 0.0001 & - & - & - & - & 0.0110 & - & - \\
\hline 033 & - & - & - & - & - & 0.0001 & - & - \\
\hline 034 & - & - & - & - & - & 0.0003 & - & - \\
\hline 036 & - & - & - & - & - & 0.0130 & - & - \\
\hline 050 & - & - & - & - & - & - & 0.0004 & 0.0005 \\
\hline 1800 & 0.6444 & 0.9616 & 0.2124 & 0.0186 & 0.4101 & 0.9991 & 1.0000 & 0.9999 \\
\hline 3040 & -0.0080 & 0.0028 & - & - & 0.0209 & 0.0009 & - & - \\
\hline 3050 & 0.3636 & 0.0357 & 0.7876 & 0.9814 & 0.6108 & - & - & 0.0001 \\
\hline 3090 & 0.3556 & 0.0384 & 0.7876 & 0.9814 & 0.5899 & 0.0009 & - & 0.0001 \\
\hline 7000 & 1.0000 & 1.0000 & 1.0000 & 1.0000 & 1.0000 & 1.0000 & 1.0000 & 1.0000 \\
\hline
\end{tabular}


Backward linkage index of sector (Sand Iron and Iron Ore) obtained by adding the invers matrix in the sector (sand iron and iron ore) $=$ $0.0262+0.0013+\ldots+0.0005=1.5826$ then divided by the number of cells in the invers matrix 1.5653 so the result is 1.0111 . Other sectors can be calculated using the same method, results can be seen in Table 5 . Sand/iron ore is a sector with the biggest backward linkage index, amounting to 1.0111 and the value is greater than 1 . It means, its backward linkage is greater than the average other economic sectors. In other words, the dependence of other domestic sectors to get input from this sector for production process is quite large (Table 5). While the backward linkage index for another seven sectors is < 1 , it means that all seven sectors have not been able to provide an optimal effect as inputs for other economic sectors in the country. Accordingly, there should be an effort to make the management of mineral resources better in order to provide benefits to other sectors.

Direct forward linkage index is a linkage of the sector to the output of the other sectors. For example, if there is an increase in the output of sector $i$, so the output will be used directly as inputs by other sectors (eg sector j). So that if the output value of the sector $i$ increases, the value of the sector input $j$ will also increase, and the value is calculated using Equation (8). Still in the same table, it appears that the forward linkage index of gold sector was 1.1144 greater than average value of all domestic metal mining sectors. It means, any changes in final demand caused by other economic sectors amounting to one unit of rupiah, then this sector will quickly absorb and utilize as an input to produce a greater output than the previous one.

\section{Direct and Indirect Linkages}

The observed result from calculation of the Leontief inverse matrix using formula in Equation (6), is presented in Table 5. The result shows that all 8 sectors are able to create direct and indirect linkage, either to the sector itself or to the other national economic sectors. For example, in iron sand/iron ore sector, for each increase in final demand of one unit rupiah, not only able to increase the output of the sector itself becomes 1.00068 , but also (indirectly) able to raise other outputs, such as agricultural sector amounted to 0.02619 , coal and lignite amounted to
0.00127 , gas/geothermal about 0.00531 , and 0.00054 for any other service sectors (except for railway sector and other transportation services). The same thing happened in tin sector, any increases in final demand of this sector could have a positive impact on the increase of other domestic economic sectors, except the two sectors previously mentioned. While for bauxite, with the increase of one unit rupiah in final demand, it can not increase its output. But for other domestic sectors, the increase is quite significant. In general, the sectors in the metal mining sector (Table 6) are able to show the real and massive trade transactions, so almost all of the other domestic sectors affected by the increase in final demand of each sector in the group. With an output of Rp. 1.00, iron sand and iron ore sectors are the largest sectors creates direct and indirect linkage that is equal to 1.48259 . Followed by nickel sector of 1.46790 , gold sector of 1.39464 and copper of 1.37639 (Table 6).

\section{Value-added}

In the structure of input-output table for 54 sectors, metal mining subsector comprises iron sand/iron ore, tin, bauxite, copper, nickel, gold, silver and other metal mining products. Gross Domestic Product (GDP) basically is a number of value added (Harahap and Koestoer, 2014) generated by all business units within a particular country, or a total value of final goods and services produced by all economic units (Hanim, 2015; BPS, 2016). In the Input-Output table, value added metal mining sector amounted to Rp. 104.32 trillion (Table 3 ), it means this sector only contributes $0.09 \%$ of the total value added of the National (Rp. 6,683.68 trillion).

To generate the production output, the sector still uses inputs from abroad (imports). As shown in Table 3, to produce iron sand/iron ore as one unit product needed domestic intermediate input amounted to $87.46 \%$, while import amounted to $12.54 \%$. Nickel sector use domestic intermediate input amounted to $78.48 \%$ and $21.52 \%$ for imports. Copper is the most major sectors of use intermediate inputs from abroad: $29.52 \%$ (Figure 1). This is because the goods and services are not yet available in the country so the sector imports them. 
Analysis of the Linkage of Metals Mining Sector with National Economic, Triswan Suseno et al.

Table 5. Backward linkage index and forward linkage index of metal mining sectors

\begin{tabular}{|c|c|c|c|c|}
\hline \multicolumn{3}{|c|}{ Sector } & Backward linkage index & Forward linkage index \\
\hline \multicolumn{3}{|c|}{ Iron Sand and Iron Ore } & 1.0111 & 0.6700 \\
\hline \multicolumn{3}{|l|}{ Tin } & 0.7742 & 0.8222 \\
\hline \multicolumn{3}{|l|}{ Bauxite } & 0.6884 & 0.6536 \\
\hline \multicolumn{3}{|l|}{ Copper } & 0.8793 & 0.6533 \\
\hline \multicolumn{3}{|l|}{ Nickel } & 0.9378 & 0.6836 \\
\hline \multirow{2}{*}{\multicolumn{3}{|c|}{$\begin{array}{l}\text { Other } \\
\text { Group }\end{array}$}} & & \\
\hline & & & 0.7284 & 0.6714 \\
\hline \multicolumn{3}{|l|}{$\begin{array}{l}\text { Gold } \\
\text { Silver }\end{array}$} & 0.8909 & 1.1144 \\
\hline \multicolumn{3}{|l|}{ Silver } & 0.7533 & 0.7140 \\
\hline
\end{tabular}

Source: BPS (2016), reprocessed

Table 6. Direct and indirect linkage in metal mining sector to other economic sectors for domestic market

\begin{tabular}{|c|c|c|c|c|c|c|c|c|}
\hline $\begin{array}{l}\text { Sector } \\
\text { code }\end{array}$ & $\begin{array}{l}\text { Iron Sand } \\
\text { and Iron Ore }\end{array}$ & Tin & Bauxite & Copper & Nickel & $\begin{array}{l}\text { Other Metals Mining } \\
\text { Goods Group }\end{array}$ & Gold & Silver \\
\hline 001 & 0.02619 & 0.01010 & 0.00376 & 0.01642 & 0.02310 & 0.00745 & 0.01687 & 0.00751 \\
\hline 002 & 0.00127 & 0.00053 & 0.00020 & 0.00090 & 0.00120 & 0.00037 & 0.00087 & 0.00039 \\
\hline 003 & 0.00523 & 0.00218 & 0.00081 & 0.00351 & 0.00501 & 0.00162 & 0.00370 & 0.00164 \\
\hline 004 & 0.00531 & 0.00207 & 0.00077 & 0.00342 & 0.00473 & 0.00151 & 0.00343 & 0.00153 \\
\hline 005 & 1.00068 & 0.00003 & 0.00001 & 0.00006 & 0.00008 & 0.00002 & 0.00004 & 0.00002 \\
\hline 006 & 0.00089 & 1.00051 & 0.00017 & 0.00091 & 0.00103 & 0.00030 & 0.00023 & 0.00011 \\
\hline 007 & 0.00006 & 0.00001 & $1,00,000$ & 0.00002 & 0.00002 & 0.00001 & 0.00001 & 0.00000 \\
\hline 008 & 0.00005 & 0.00060 & 0.00022 & 1.00118 & 0.00129 & 0.00037 & 0.00011 & 0.00006 \\
\hline 009 & 0.00016 & 0.00034 & 0.00012 & 0.00066 & 1.00079 & 0.00021 & 0.00008 & 0.00004 \\
\hline 010 & 0.00026 & 0.00006 & 0.00002 & 0.00010 & 0.00013 & 1.00004 & 0.00007 & 0.00003 \\
\hline 011 & 0.00174 & 0.00063 & 0.00023 & 0.00120 & 0.00136 & 0.00039 & 1.04093 & 0.01876 \\
\hline 012 & 0.00031 & 0.00006 & 0.00002 & 0.00010 & 0.00013 & 0.00004 & 0.00198 & 1.00091 \\
\hline 013 & 0.00740 & 0.00169 & 0.00061 & 0.00314 & 0.00369 & 0.00109 & 0.00148 & 0.00068 \\
\hline 014 & 0.00048 & 0.00007 & 0.00003 & 0.00013 & 0.00015 & 0.00004 & 0.00005 & 0.00002 \\
\hline 015 & 0.00001 & 0.00000 & 0.00000 & 0.00001 & 0.00001 & 0.00000 & 0.00001 & 0.00000 \\
\hline 016 & 0.00014 & 0.00006 & 0.00002 & 0.00010 & 0.00014 & 0.00005 & 0.00012 & 0.00005 \\
\hline 017 & 0.03879 & 0.03057 & 0.01100 & 0.05947 & 0.06576 & 0.01884 & 0.02432 & 0.01140 \\
\hline 018 & 0.13022 & 0.05434 & 0.02029 & 0.08738 & 0.12503 & 0.04050 & 0.09215 & 0.04095 \\
\hline 019 & 0.00677 & 0.00108 & 0.00039 & 0.00204 & 0.00236 & 0.00069 & 0.00100 & 0.00046 \\
\hline 020 & 0.00353 & 0.00063 & 0.00023 & 0.00116 & 0.00138 & 0.00041 & 0.00065 & 0.00030 \\
\hline 021 & 0.00004 & 0.00001 & 0.00000 & 0.00001 & 0.00002 & 0.00001 & 0.00001 & 0.00000 \\
\hline 022 & 0.00644 & 0.00093 & 0.00034 & 0.00178 & 0.00201 & 0.00058 & 0.00069 & 0.00032 \\
\hline 023 & 0.00005 & 0.00001 & 0.00000 & 0.00001 & 0.00002 & 0.00000 & 0.00001 & 0.00000 \\
\hline 024 & 0.00018 & 0.00006 & 0.00002 & 0.00011 & 0.00013 & 0.00004 & 0.00008 & 0.00004 \\
\hline 025 & 0.00107 & 0.00038 & 0.00014 & 0.00069 & 0.00083 & 0.00024 & 0.00114 & 0.00052 \\
\hline 026 & 0.00018 & 0.00007 & 0.00003 & 0.00012 & 0.00016 & 0.00005 & 0.00016 & 0.00008 \\
\hline 027 & 0.00096 & 0.00003 & 0.00001 & 0.00006 & 0.00006 & 0.00002 & 0.00014 & 0.00006 \\
\hline 028 & 0.00043 & 0.00026 & 0.00009 & 0.00049 & 0.00057 & 0.00016 & 0.00082 & 0.00036 \\
\hline 029 & 0.00020 & 0.00006 & 0.00002 & 0.00011 & 0.00013 & 0.00004 & 0.00012 & 0.00006 \\
\hline 030 & & & & & & & 66 & 30 \\
\hline 031 & 029 & 0.00 & 0.0 & 0.0 & 0.0 & 25 & 077 & 0.00036 \\
\hline 032 & 0.00013 & 0.00007 & 0.00002 & 0.00013 & 0.00015 & 0.00004 & 0.00014 & 0.00006 \\
\hline 033 & 0.00080 & 0.00369 & 0.00126 & 0.00745 & 0.00804 & 0.00229 & 0.00275 & 0.00127 \\
\hline 034 & 0.00652 & 0.00672 & 0.00251 & 0.01385 & 0.01584 & 0.00454 & 0.01850 & 0.00845 \\
\hline 035 & 0.01183 & 0.00202 & 0.00073 & 0.00381 & 0.00437 & 0.00126 & 0.00795 & 0.00365 \\
\hline 036 & 0.00004 & 0.00002 & 0.00001 & 0.00003 & 0.00003 & 0.00001 & 0.00002 & 0.00001 \\
\hline 037 & 0.00000 & 0.00000 & 0.00000 & 0.00000 & 0.00000 & 0.00000 & 0.00000 & 0.00000 \\
\hline 038 & 0.00013 & 0.00007 & 0.00003 & 0.00014 & 0.00016 & 0.00005 & 0.00010 & 0.00005 \\
\hline 039 & 0.00000 & 0.00000 & 0.00000 & 0.00000 & 0.00000 & 0.00000 & 0.00000 & 0.00000 \\
\hline 040 & 0.00477 & 0.00264 & 0.00096 & 0.00480 & 0.00577 & 0.00170 & 0.00455 & 0.00208 \\
\hline 041 & 0.00095 & 0.00036 & 0.00013 & 0.00064 & 0.00082 & 0.00025 & 0.00060 & 0.00027 \\
\hline 042 & 0.00059 & 0.00039 & 0.00014 & 0.00072 & 0.00084 & 0.00025 & 0.00033 & 0.00015 \\
\hline 043 & 0.16675 & 0.02336 & 0.00842 & 0.04508 & 0.05031 & 0.01444 & 0.01620 & 0.00759 \\
\hline 044 & 0.04975 & 0.01459 & 0.00557 & 0.02586 & 0.03147 & 0.00934 & 0.04435 & 0.02022 \\
\hline 045 & 0.04415 & 0.02504 & 0.00930 & 0.04560 & 0.05320 & 0.01525 & 0.03471 & 0.01602 \\
\hline
\end{tabular}


INDONESIAN MINING JOURNAL Vol. 22, No. 2, October $2019: 129$ - 143

\begin{tabular}{ccccccccc}
\hline $\begin{array}{c}\text { Sector } \\
\text { code }\end{array}$ & $\begin{array}{c}\text { Iron Sand } \\
\text { and Iron Ore }\end{array}$ & Tin & Bauxite & Copper & Nickel & $\begin{array}{c}\text { Other Metals Mining } \\
\text { Goods Group }\end{array}$ & Gold & Silver \\
\hline 046 & 0.00331 & 0.00121 & 0.00040 & 0.00221 & 0.00237 & 0.00078 & 0.00191 & 0.00084 \\
047 & 0.02096 & 0.00504 & 0.00182 & 0.00901 & 0.01099 & 0.00319 & 0.01614 & 0.00738 \\
048 & 0.02028 & 0.00605 & 0.00219 & 0.01154 & 0.01358 & 0.00406 & 0.01565 & 0.00668 \\
049 & 0.00144 & 0.00054 & 0.00020 & 0.00095 & 0.00117 & 0.00034 & 0.00123 & 0.00056 \\
050 & 0.00657 & 0.01071 & 0.00353 & 0.01565 & 0.02316 & 0.00596 & 0.03296 & 0.01516 \\
051 & 0.00179 & 0.00054 & 0.00019 & 0.00094 & 0.00118 & 0.00035 & 0.00282 & 0.00129 \\
052 & 0.00033 & 0.00021 & 0.00008 & 0.00040 & 0.00046 & 0.00013 & 0.00023 & 0.00010 \\
053 & 0.00049 & 0.00031 & 0.00010 & 0.00055 & 0.00067 & 0.00020 & 0.00048 & 0.00022 \\
054 & 0.00054 & 0.00021 & 0.00008 & 0.00037 & 0.00045 & 0.00013 & 0.00032 & 0.00015 \\
\hline Sum & 1.58259 & 1.21188 & 1.07748 & 1.37639 & 1.46790 & 1.1401 & 1.39464 & 1.17916 \\
\hline
\end{tabular}

Source: BPS (2016), reprocessed.

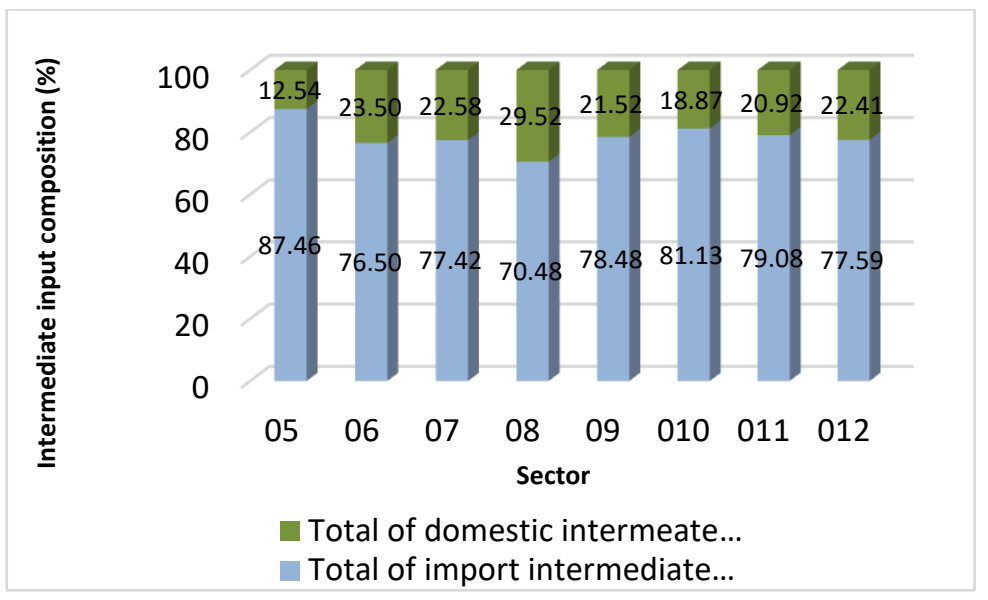

Figure 1. Structure of intermediate input in metals mining sector

In producing its products, the metal mineral mining sector requires intermediate inputs by $29 \%$, but results in added value by $71 \%$. Bauxite is a sector that is able to create the greatest added value that is $94 \%$ while the input requirements of which only $6 \%$.

\section{Trade Balance}

The trade balance is the ratio between the value of exports to the value of imports, if the ratio is greater than 1 means that the sector is experiencing a surplus. If otherwise, that sector is deficit. The trade balance is said to be balanced when the ratio is equal to 1 . In this case, the sector had a deficit due to the ratio is less than 1 is mining gold, silver, tin and other metallic minerals.

The greatest deficit is gold mining sector, which amounted to Rp. 2.4 trillion, mainly imported from other machinery sector, equipment and processing industry. The same thing also experienced by silver mining sector amounted to Rp. 225.64 billion, tin
Rp.78,59 billion and other metal mining goods Rp.86,00 billion. In other words, those four sectors still have high degree of dependence on goods from abroad. Therefore, there should be same industries in the country to meet the needs of mining industry as an effort to reduce production costs, and preparing for the free trade.

Copper mining sector experiences the largest surplus among other mining sectors, amounting to Rp. 55.90 trillion, and becomes the biggest contributor in creating the gross domestic product metal mining sector (Table 7). It is due to $70 \%$ of the product is export-oriented and the rest is utilized only by single domestic industry. In the near future, in order to increase the added value, the copper should not only concentrated in export-oriented but also should processed in domestic by building smelter. Other sectors that shows the surplus trade is the sector iron sand/iron ore with grades $\mathrm{Rp}$. 1.54 trilioun, bauxite $\mathrm{Rp}$. 4.36 trillion, and nickel by Rp. 4.65 trillion. 
Table 7. The trade balance of Indonesia based Input-Output in 2010 (million rupiah)

\begin{tabular}{crrrr}
\hline Sector code & \multicolumn{1}{c}{ Export } & \multicolumn{1}{c}{ Import } & Deficit/Surplus & Ratio \\
\hline 005 & $1,774,841$ & 232,600 & $1,542,241$ & 7.63 \\
006 & 634,947 & 713,536 & $-78,589$ & 0.89 \\
007 & $4,442,290$ & 78,417 & $4,363,873$ & 56.65 \\
008 & $62,093,084$ & $6,190,954$ & $55,902,130$ & 10.03 \\
009 & $5,333,857$ & 688,781 & $4,645,076$ & 7.74 \\
010 & - & 85,999 & $-85,999$ & - \\
011 & 177 & $2,400,857$ & $-2,400,680$ & - \\
012 & 439 & 226,083 & $-225,644$ & - \\
\hline
\end{tabular}

Source: BPS (2016), reprocessed

Although the metal mining sector gives only a small contribution to the formation of the structure of the national economy in the form of gross domestic product, but it is not as small as its role in trade transactions between sectors in the country. It can be seen by calculation of analysis using inputoutput tables, explained that this sector has a high exposure to other economic sectors in the country, both backward and forward as measured by the index of the spread and degree of sensitivity.

I-O tables explain all sectors of the economy and provide more specific information. It means that the presence of the mineral mining sector could encourage to create interdependence among sectors in the domestic economy. These linkages can be seen from the output side as well as from the input side (Yu, 2018). The linkage of the output due to the production of the sector will be used as inputs into other sectors or backward linkage, while linkage from the input side arising from the sector which uses the input from other sectors or forward linkage.

\section{CONCLUSION AND SUGGESTIONS}

\section{Conclusion}

Based on the above discussion, some conclusions can be drawn as follows:

1) Copper, nickel and gold sectors have the highest upstream linkages, because they are able to absorb inputs from 27 sectors in the country.

2) The bauxite sector is the smallest sector utilizing inputs (products) from other sectors in the country that is only 0.0477 , mostly imported.

3) In terms of downstream linkages, bauxite, copper and nickel sectors are 3 sectors whose output is the least utilized by other sectors in the country, namely $0.2124,0.0186$ and 0.4101 . In other words, most of its output is sold or exported. This shows that the absence of domestic industry is able to utilize products from these 3 sectors due to technology limitations.

4) With an output of Rp. 1.00, iron sand and iron ore sectors are the largest sectors creates direct and indirect linkage that is equal to 1.48259 , followed by the nickel sector of 1.46790 , the gold sector of 1.39464 and copper of 1.37639 .

5 ) In producing its products, the metal mineral mining sector requires $29 \%$ of the inputs but produces added value of $71 \%$. Bauxite is the sector that is able to create the biggest added value that is $94 \%$ while the input needs are only $6 \%$.

\section{Suggestions}

Considering the increase use of domestic production in metal mining sector, and the capability to create high linkages to the other national sectors, there should be necessary steps to encourage the productivity of this sector, which is previously only sold as ore and raw materials. One of the steps is by increasing the availability of processing and purification technologies facility (smelter) of metallic minerals. The final demand of this smelter industry will create greater output in metal mining sector, so that productivity will increase as well.

\section{REFERENCES}

Ayas, N. (2017) 'Import dependency of sectors and major determinants: An input output analysis', European Journal of Sustainable Development Research, 2(1), pp. 1-16. 
Bekhet, H. A. and Abdullah, A. (2010) 'Energy use in agriculture sector: Input-output analysis', International Business Research, 3(3), p. 111. doi: 10.5539/ibr.v3n3p111.

BPS (2010) Tabel input-output Indonesia 2010. Jakarta: Badan Pusat Statistik.

BPS (2016) Produk domestik bruto Indonesia menurut lapangan usaha tahun 2000 2015 atas dasar harga konstan tahun 2000. Jakarta: Badan Pusat Statistik.

Bulmer-Thomas, V. (1982) Input-output analysis in developing countries: Sources, methods, and applications. Chichester: Wiley.

Chifamba, R. T. and Odhiambo, O. (2015) 'An analysis of the potential of manufacturing and services sectors as drivers of economic growth and development in Namibia', Business and Management Studies, 1(2), pp. 167-178. doi: 10.11114/bms.v1i2.1046.

Chiu, R.-H. and Lin, Y.-C. (2012) 'Applying inputoutput model to investigate the interindustrial linkage of transportation industry in Taiwan', Journal of Marine Science and Technology, 20(2), pp. 173-186.

Dault, A., Mudzakir, A. K. and Suherman, A. (2008) 'Analisis keterkaitan dan dampak pengganda sektor perikanan pada perekonomian Jawa Tengah: Analisis input output', Jurnal Saintek Perikanan, 4(1), pp. 1-8. doi: 10.14710/ijfst.4.1.1-8.

Gaspersz, V. (1992) Analisis sistem terapan berdasarkan pendekatan teknik industri. Bandung: Tarsito.

Hanim, W. (2015) 'Menggali potensi ekonomi lokal dengan pendekatan input-output: Studi di Propinsi Kalimantan Selatan', Jurnal Akuntansi Bisnis dan Ekonomi, 1(1), pp. 57-66.

Harahap, R. M. and Koestoer, R. H. (2014) 'Spatial distribution of key sectors of West Kalimantan, Indonesia', Jurnal Ekonomi Pembangunan, 15(1), pp. 46-54.

Karkacier, O. and Bölük, G. (2017) 'The structural analysis of agriculture, food and energy sectors In Turkey: An input-output Model', Injosos Al-Farabi International Journal on Social Sciences, 1(2), pp. 289-305.

Ke, W. et al. (2016) 'A multi-objective input-output linear model for water supply, economic growth and environmental planning in resource-based cities', Sustainability, 8(2), p. 160. doi: 10.3390/su8020160.

Kula, M. (2008) 'Supply-use and input-output tables, backward and forward linkages of the Turkish economy', in The 16th Inforum World Conference in Northern Cyprus, pp. 1-20.

Marconi, N., Rocha, I. L. and Magacho, G. R. (2016) 'Sectoral capabilities and productive structure: An input-output analysis of the key sectors of the Brazilian economy', Revista de Economia Política, 36(3), pp. 470-492. doi: 10.1590/0101-31572016v36n03a02.

Mellyawanty, W. O. et al. (2012) Analisis inputoutput(I-O). Universitas Muhammadiyah Yogyakarta.

Mirza, M., Marwa, T. and Mukhlis, M. (2015) 'Linkage analysis of cement industry in the Indonesian economy: Input-output analysis', Eurasian Journal of Economics and Finance, 3(4), pp. 48-55. doi: 10.15604/ejef.2015.03.04.005.

Muryani, M. and Swastika, R. B. (2018) 'Inputoutput analysis: A case stury of transportation sector in Indonesia', Journal of Developing Economies, 3(2), p. 26. doi: 10.20473/jde.v3i2.9650.

Nahib, I. (2006) 'Pengelolaan sumberdaya tidak pulih berbasis ekonomi sumberdaya (Studi kasus: tambang minyak blok cepu)', Jurnal IImiah Geomatika, 12(1), pp. $37-50$.

Nazara, S. (1997) Analisis input-output. Jakarta: Universitas Indonesia.

Pangaribuan, O. E. (2014) Penerapan model input-output dalam analisis perekonomian Provinsi Kalimantan Selatan, www.bppk.kemenkeu.go.id. Available at: https://bppk.kemenkeu.go.id/id/publikasi/ artikel/149-artikel-kekayaan-negara-danperimbangan-keuangan/19961penerapan-model-input-output-dalamanalisis-perekonomian-provinsikalimantan-selatan (Accessed: 15 January 2018).

Purnomo, D. and Istiqomah, D. (2008) 'Analisis pernana sektor industri terhadap perekonomian Jawa Tengah Tahun 2000 dan Tahun 2004 (Analisis input output)', Jurnal Ekonomi Pembangunan: Kajian Masalah Ekonomi dan Pembangunan, 9(2), p. 137. doi: 10.23917/jep.v9i2.1021. 
Analysis of the Linkage of Metals Mining Sector with National Economic, Triswan Suseno et al.

Reis, H. and Rua, A. (2006) An input-output analysis: Linkages VS leakages. Lisboa.

Stilwell, R. C. A. and Minnitt, L. C. (2000) 'Inputoutput analysis: Its potential application to the mining industry', Journal of the Southern African Institute of Mining and Metallurgy, 100(7), pp. 455-460.

Vega, V. (2013) Linkage industry, veravega.blogspot.com. Available at: http://veravega.blogspot.com/2013/11/lin kage-industry.html (Accessed: 15 January 2018).

Yu, H. (2018) 'A review of input-output models on multisectoral modelling of transportation- economic linkages', Transport Reviews, 38(5), pp. 654-677.

doi: 10.1080/01441647.2017.1406557.

Zaini, A. (2004) 'Daya penyebaran sektor pertanian dalam struktur ekonomi Propinsi Kalimantan Timur: Pendekatan input-output', EPP, 1(1), pp. 8-12.

Zhang, Q. and Felmingham, B. (2002) An analysis of input-output interindustry linkages in the PRC economy, www.researchgate.net. Available at: https://www.researchgate.net/publication /228426357_An_Analysis_of_Inputoutput Interindustry_Linkages in the P RC_Economy (Accessed: 15 January 2018). 